\title{
Antioxidant Defense Mechanisms of Endothelial Cells and Renal Tubular Epithelial Cells In Vitro: Role of the Glutathione Redox Cycle and Catalase ${ }^{1}$
}

\author{
SHARON P. ANDREOLI, COLEEN MALLETT, JAMES A. MCATEER, AND LYNN V. WILLIAMS \\ Departments of Pediatrics and Anatomy, Indiana University Medical Center, Indianapolis, Indiana 46202-5225
}

\begin{abstract}
We recently demonstrated that endothelial cells are more susceptible than renal tubular epithelial cells to oxidant injury and that renal tubular epithelial cells with proximal tubular characteristics including porcine proximal tubular epithelial cells, opossum kidney proximal tubular epithelial cells, and normal human kidney cortical epithelial cells are more susceptible to oxidant injury than the distal nephron-derived Madin Darby canine kidney cell line. To determine the basis of this differential response, we evaluated several antioxidant defenses in the five cell lines. Glutathione levels were not significantly different among the five cell lines, but catalase and glutathione reductase levels were significantly $(p<0.01)$ lower in endothelial cells compared to all renal tubular epithelial cells. Among renal tubular epithelial cells, Madin Darby canine kidney cells had significantly $(p<0.05)$ higher glutathione peroxidase activity. To further evaluate the role of antioxidant defenses in limiting oxidant injury, we determined two responses to oxidant injury (ATP depletion and ${ }^{51} \mathrm{Cr}$ release) when glutathione was depleted with buthionine sulfoxamine and when catalase was inhibited with aminotriazole. Oxidant-induced ATP depletion was accentuated when catalase was inhibited as well as when glutathione was depleted with buthionine sulfoxamine. In contrast, inhibition of catalase had little or no effect on ${ }^{51} \mathrm{Cr}$ release, whereas glutathione depletion resulted in accentuated ${ }^{51} \mathrm{Cr}$ release. We conclude that the increased susceptibility of endothelial cells to oxidant injury as compared with epithelial cells is associated with lower antioxidant defenses. Disruption of the glutathione redox cycle results in accentuated ATP depletion and lytic injury, whereas inhibition of catalase results in accentuated ATP depletion with little effect on lytic injury. Augmented oxidant-induced ATP depletion without augmented cell lysis suggests that ATP depletion alone may not be a critical mediator of cell death in oxidant stress. (Pediatr Res 32: $360-365,1992$ )
\end{abstract}

\section{Abbreviations}

BSO, buthionine sulfoxamine

LLC-PK1, porcine proximal tubular epithelial cells

MDCK, Madin Darby canine kidney cells

NHK-C, normal human kidney cortical epithelial cells

Received January 16, 1992; accepted April 17, 1992.

Correspondence and reprint requests: Sharon P. Andreoli, M.D., Department of Pediatric Nephrology, James Whitcomb Riley Hospital for Children, One Childrens Square, Indianapolis, IN 46202-5225.

Supported by grants from the American Heart Association, Indiana Affiliate, DK 20542-13 pilot project, and the Polycystic Kidney Research Foundation.

' Presented in part at the Society for Pediatric Research annual meeting, May 1990, Anaheim, CA.
o-DD, o-dianisidine-dihydrochloride

OK, opossum kidney proximal tubular epithelial cells DMEM, Dulbecco's Modified Eagle Medium

HBSS, Hanks' balanced salt solution

Reactive oxygen molecules have been shown to participate in the pathogenesis of several renal diseases including inflammatory lesions, ischemic-reperfusion injury, toxic nephropathies, and in renal infections such as pyelonephritis (1-8). Reactive oxygen molecules arise from several sources including activated polymorphonuclear cells, monocytes, and mesangial cells, during the metabolism of exogenous drugs and toxins, and during normal and abnormal metabolic processes. When oxidant generation increases, or when antioxidant defense mechanisms are decreased, oxidant injury results from the shift in the oxidant/ antioxidant balance. Oxidant stress may induce injury to proteins by oxidation of critical amino acids, may disrupt membrane integrity through lipid peroxidation, may degrade basement membranes, and may induce DNA damage by induction of strand breaks (9). When cells and organs are exposed to oxidant stress, several different antioxidant defense mechanisms exist to prevent or limit the extent of injury.

Little is known about the response of various cells within the kidney to oxidant stress. In some renal diseases, endothelial cells may be the primary target of oxidant injury, whereas renal tubular epithelial cells may be the major target of injury in other pathologic processes. We recently studied the response of human endothelial cells and four renal tubular epithelial cell lines including NHK-C (human proximal tubules), LLC-PK1 (porcine proximal tubules), OK (opossum proximal tubules), and MDCK (canine distal tubules) to oxidant stress generated with hypoxanthine-xanthine oxidase (10). In that study, we found that NHKC, LLC-PK 1, and OK cells were more easily damaged by reactive oxygen molecules than MDCK cells, whereas endothelial cells were more susceptible to oxidant injury than each of the renal tubular epithelial cell lines. Hydrogen peroxide was the reactive oxygen molecule responsible for ATP depletion and efflux of ${ }^{3} \mathrm{H}$ adenine metabolites, whereas hydrogen peroxide and an irondependent radical derived from hydrogen peroxide were responsible for cell lysis and cell detachment. Superoxide dismutase had no effect in preventing oxidant-induced ATP depletion, efflux of ATP metabolites, cell detachment, or cell lysis (10).

In this study, we investigated the basis for the differential response of the five cell lines to oxidant stress and we determined the role of the glutathione redox cycle and catalase in protecting the cells from oxidant-induced ATP depletion and lytic injury. Because we previously found that hydrogen peroxide played a central role in mediating oxidant-induced endothelial and epi- 
thelial cell injury, we specifically examined the activity of enzymes important in metabolizing hydrogen peroxide including the glutathione redox cycle and catalase. We found that the mechanism of increased susceptibility of endothelial cells to oxidant injury is associated with lower activities of catalase, glutathione reductase, and glutathione peroxidase, which are important in detoxifying reactive oxygen molecules. In addition, we demonstrate that the glutathione redox cycle is important in maintaining cell integrity, whereas catalase as well as the glutathione redox cycle is important in preventing oxidant-induced ATP depletion. Interestingly, we found that augmented oxidantinduced ATP depletion is not associated with augmented lytic injury, suggesting that ATP depletion alone may not be responsible for oxidant-induced cell death.

\section{MATERIALS AND METHODS}

Cell culture. Renal tubular epithelial cell lines LLC-PK1 (CRL 139) and MDCK (CCL 34) were obtained from the American Type Culture Collection (Rockville, MD) $(11,12)$. OK cells were provided by Professor H. Murer, Zurich, Switzerland. The MDCK, LLC-PK1, and OK cell lines are multiple-passage cell lines that have been extensively characterized and are widely used as models of proximal (LLC-PK1 and OK) and distal (MDKC) tubular epithelial cell lines. NHK-C cells were derived from fragments of human kidney cortex by progressive enzymatic dissociation; this cell line has recently been characterized as proximal tubular-like and has a limited life-span of approximately five to seven passages (13). Tubular epithelial cells were grown in DMEM and nutrient medium F12 (1:1) (JRH Biosciences, Lenexa, KS) supplemented with $100 \mathrm{U} / \mathrm{mL}$ penicillin, 10 $\mathrm{mM} N$-2-hydroxyethylpiperazine- $N^{\prime}$-2-ethanesulfonic acid, and $10 \%$ FCS (Sterile Systems, Logan, UT) at $37^{\circ} \mathrm{C}$ in a humidified atmosphere containing $5 \% \mathrm{CO}_{2}$ in air. Human endothelial cells were obtained from umbilical veins by collagenase digestion and identified as previously described; these cells have a limited in vitro life-span of approximately four to six passages $(10,14)$. For optimal growth, endothelial cells were first cultured in M199. For experimental studies, all cell lines including endothelial cells were subcultured in 24-well culture plates in DMEM/F12; experiments were performed 3-4 d later. M199 and DMEM/F12 each contain sufficient elemental iron for catalase activity (1.78 and $1.62 \mu \mathrm{M}$ elemental iron, respectively). For each cell line, studies were performed on cultures over a range of no more than five passages.

Biochemical assays. Chemicals were obtained from Sigma Chemical Co. (St. Louis, MO), unless otherwise stated. Total glutathione levels were determined as previously described by the method of Tietze $(15,16)$. The cell monolayers were washed twice in HBSS (GIBCO, Grand Island, NY), then solubilized with $300 \mu \mathrm{L}$ of $0.5 \%$ Triton X-100. Glutathione levels were determined at $37^{\circ} \mathrm{C}$ with $100 \mu \mathrm{L}$ of sample or standard, $20 \mu \mathrm{L}$ of $25 \mathrm{U} / \mathrm{mL}$ glutathione reductase, $800 \mu \mathrm{L}$ of $0.3 \mathrm{mM}$ NADPH in $125 \mathrm{mM}$ sodium phosphate buffer with $6.3 \mathrm{mM}$ EDTA, $\mathrm{pH} 7.5$, and $100 \mu \mathrm{L}$ of $6 \mathrm{mM} 5^{\prime}-5^{\prime}$-dithiobis-2-nitrobenzoic acid. The change in OD was measured at $412 \mathrm{~nm}$ and monitored continuously on a Pye-Unicam spectrophotometer (Unicam Instruments, Cambridge, England). The glutathione content was quantitated by comparison with a standard curve generated with known amounts of glutathione. Glutathione peroxidase and glutathione reductase activities were determined by oxidation of NADPH (17). Briefly, endothelial and epithelial cells in T25 flasks were washed free of media, dissolved in $600 \mu \mathrm{L}$ cold $0.5 \%$ Triton, and scraped off the flask. For glutathione peroxidase activity, $100 \mu \mathrm{L}$ and $200 \mu \mathrm{L}$ of sample or standard were added to $50 \mathrm{mM}$ sodium phosphate buffer containing $0.6 \mathrm{mM}$ sodium azide, $0.25 \mathrm{mM}$ glutathione, $0.125 \mathrm{mM}$ NADPH, 0.4 units glutathione reductase, and $0.073 \mathrm{mM}$ hydrogen peroxide. The decrease in OD was monitored continuously at $366 \mathrm{~nm}$ at $37^{\circ} \mathrm{C}$. Glutathione peroxidase activity was quantitated by comparison with a standard curve generated with known amounts of glutathione peroxidase. Glutathione reductase was determined with 50 and $100 \mu \mathrm{L}$ of sample or standard with $100 \mathrm{mM}$ sodium phosphate buffer containing $1.3 \mathrm{mM}$ glutathione and $0.1 \mathrm{mM}$ NADPH. The change in OD was measured at $366 \mathrm{~nm}$ at $37^{\circ} \mathrm{C}$. Glutathione reductase was quantitated with a standard curve generated with known amounts of glutathione reductase. Catalase was determined by metabolism of hydrogen peroxide with a spectrophotometric assay using o-DD (18). Briefly, endothelial and epithelial cells were washed with HBSS then solubilized with $0.5 \%$ Triton $\mathrm{X}-100$. Twenty-five to $100 \mu \mathrm{L}$ of sample or standard were incubated for $10 \mathrm{~min}$ at $25^{\circ} \mathrm{C}$ with $400 \mu \mathrm{L}$ of $0.6 \mathrm{mM}$ hydrogen peroxide. After $10 \mathrm{~min}, 100 \mu \mathrm{L}$ of $6 \mathrm{mM}$ sodium azide were added. The amount of hydrogen peroxide remaining was quantitated with $0.25 \mathrm{mM}$ o-DD and $10 \mathrm{U}$ horseradish peroxidase. The change in OD was determined at $470 \mathrm{~nm}$. Catalase was quantitated with a standard curve generated with known amounts of catalase. Protein content was determined on a portion of the cell sample (19); glutathione, glutathione peroxidase, glutathione reductase, catalase, and ATP levels were each normalized per mg of cell protein.

Hydrogen peroxide metabolism. Hydrogen peroxide degradation was determined by incubating monolayers in 24-well plates with $400 \mathrm{nmol}$ of hydrogen peroxide in $400 \mu \mathrm{L}$ of HBSS containing $1 \%$ albumin. The degradation of hydrogen peroxide was determined at $37^{\circ} \mathrm{C}$ for $15,30,45,60,75$, and $90 \mathrm{~min}$. The amount of hydrogen peroxide remaining at each time was determined by reaction with o-DD as previously described $(10,18)$. The time required for disappearance of half the hydrogen peroxide was calculated to determine the half life.

Inhibition studies. To investigate the relative role of the glutathione redox cycle and catalase in preventing oxidant-induced ATP depletion and lytic injury, we determined ATP depletion and ${ }^{51} \mathrm{Cr}$ release in cells exposed to oxidant stress when glutathione was depleted with BSO and when catalase was inhibited with aminotriazole. BSO results in glutathione depletion through inhibition of $\gamma$-glutamylcysteine synthetase, whereas aminotriazole is a specific inhibitor of catalase by combining with compound I (hydrogen peroxide complexed with catalase) $(20,21)$. Endothelial and epithelial cells were preincubated overnight with $2.5 \mathrm{mM}$ BSO. For the studies using aminotriazole, endothelial cells were preincubated for $30 \mathrm{~min}$ with $1 \mathrm{mg} / \mathrm{mL}$ aminotriazole and renal epithelial cells were preincubated with $2.5 \mathrm{mg} / \mathrm{mL}$ aminotriazole; BSO and aminotriazole were also included when cells were exposed to the reactive oxygen molecule generating system. Because of the variable susceptibility of the cells to oxidant stress, endothelial cells were exposed to $12.5 \mathrm{mU} / \mathrm{mL}$ xanthine oxidase (Boehringer Mannheim, Indianapolis, IN), NHK-C and LLC-PK1 cells were exposed to $25 \mathrm{mU} / \mathrm{mL}$ xanthine oxidase and MDCK cells and OK cells were exposed to 50 $\mathrm{mU} / \mathrm{mL}$ xanthine oxidase. Soybean trypsin inhibitor, $1.0 \mathrm{mg} /$ $\mathrm{mL}$, was included with the xanthine oxidase to inhibit the effects of contaminating protease enzymes (22).

ATP levels. ATP levels were measured on replicate cultures of endothelial and epithelial cells with luciferin-luciferase as an early response to oxidant injury as previously described $(10,23-$ 25). After a 1-h exposure to the oxygen radical generating system, cells were solubilized with $500 \mu \mathrm{L} 0.5 \%$ Triton and acidified with $100 \mu \mathrm{L} 0.6 \mathrm{M}$ perchloric acid and placed on ice until assayed. At the time of assay, the cell suspension was diluted with $10 \mathrm{mM}$ potassium phosphate buffer containing $4 \mathrm{mM}$ $\mathrm{MgSO}_{4}(\mathrm{pH} 7.4$ ); $500 \mu \mathrm{L}$ of this were added to $1 \mathrm{~mL}$ of $50 \mathrm{mM}$ sodium arsenate buffer containing $20 \mathrm{mM} \mathrm{MgSO}_{4}$ (pH 7.4) to which $25 \mu \mathrm{L}$ of $40 \mathrm{mg} / \mathrm{mL}$ luciferin-luciferase was added. Light emission was recorded ;recisely at $20 \mathrm{~s}$ with a Packard beta counter accepting signals out of coincidence (23). Protein content was determined on a portion of the cell sample and ATP was expressed as $\mathrm{pmol} / \mu \mathrm{g}$ cell protein (19).

${ }^{51} \mathrm{Cr}$ release. Late, lytic injury and cell detachment were determined by ${ }^{51} \mathrm{Cr}$ release in cells that were radiolabeled with 2.5 
Table 1. Glutathione levels and activity of glutathione peroxidase (GPX), glutathione reductase (GR), and catalase in each cell type*

\begin{tabular}{lccrc}
\hline Cell line & $\begin{array}{c}\text { Glutathione } \\
\text { (nmol/mg } \\
\text { protein) }\end{array}$ & $\begin{array}{c}\text { GPX (mU/mg } \\
\text { protein) }\end{array}$ & $\begin{array}{c}\text { GR (mU/mg } \\
\text { protein) }\end{array}$ & $\begin{array}{c}\text { Catalase (U/. } \\
\text { mg protein) }\end{array}$ \\
\hline LLC-PK1 & $21.9 \pm 7.1$ & $13.0 \pm 2.2$ & $18.8 \pm 1.8 \dagger$ & $29.2 \pm 0.8 \ddagger$ \\
MDCK & $25.5 \pm 8.9$ & $21.8 \pm 2.9 \ddagger$ & $11.0 \pm 2.9$ & $31.3 \pm 2.1 \ddagger$ \\
NHK-C & $20.2 \pm 1.6$ & $16.4 \pm 2.3$ & $9.3 \pm 2.1$ & $8.1 \pm 0.5 \ddagger$ \\
OK & $28.3 \pm 5.9$ & $16.1 \pm 2.9$ & $11.1 \pm 1.0$ & $15.2 \pm 3.4 \ddagger$ \\
EC & $26.6 \pm 5.1$ & $12.1 \pm 2.7 \S$ & $5.2 \pm 1.8 \|$ & $3.5 \pm 1.0 \|$ \\
\hline
\end{tabular}

* Values represent the mean \pm 1 SD of four to six separate cohorts of cells. EC, human umbilical vein endothelial cells.

$\dagger p<0.05$ compared with MDCK, OK, and NHK-C.

$\ddagger p<0.05$ compared with all other cells.

$\S p<0.05$ compared with MDCK, NHK-C, and OK cells.

$\| p<0.001$ compared with all other cells.

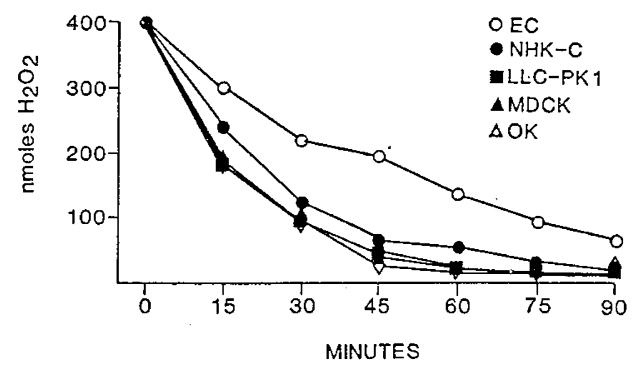

Fig. 1. The consumption of hydrogen peroxide in LLC-PK1, OK, NHK-C, MDCK, and human umbilical vein endothelial cell $(E C)$ monolayers in 24-well plates when incubated with $400 \mathrm{nmol}$ of hydrogen peroxide in $400 \mu \mathrm{L}$ HBSS $+1 \%$ albumin. Metabolism of hydrogen peroxide was significantly $(p<0.01)$ slower in endothelial cells compared with epithelial cells. Among renal tubular epithelial cells, NHK-C cells metabolized hydrogen peroxide at a slightly but significantly $(p<0.01)$ slower rate. Values represent the mean of four replicates; the SD of each value is less than 7.5 .

Table 2. Glutathione levels and catalase activity in cells exposed to BSO or aminotriazole*

\begin{tabular}{|c|c|c|}
\hline Cell line & $\begin{array}{l}\text { Glutathione in cells } \\
\text { exposed to BSO } \\
\text { [nmol/mg protein } \\
(\% \text { control })]\end{array}$ & $\begin{array}{l}\text { Catalase in cells } \\
\text { exposed to Ami- } \\
\text { notriazole [U/mg } \\
\text { protein (\% con- } \\
\text { trol)] }\end{array}$ \\
\hline LLC-PK1 & $2.3 \pm 1.2(10.5 \%)$ & $2.9 \pm 2.5(9.9 \%)$ \\
\hline MDCK & $4.5 \pm 3.9(17.6 \%)$ & $2.1 \pm 1.7(7.2 \%)$ \\
\hline NHK-C & $5.4 \pm 1.8(26.7 \%)$ & $1.2 \pm 0.9(14.8 \%)$ \\
\hline OK & $3.2 \pm 1.3(11.3 \%)$ & $2.6 \pm 2.1(17.1 \%)$ \\
\hline $\mathrm{EC}$ & $6.7 \pm 3.9(25.1 \%)$ & $0.7 \pm 0.4(20.0 \%)$ \\
\hline
\end{tabular}

* Cells were incubated in $2.5 \mathrm{mM}$ BSO overnight or in aminotriazole $(1.0 \mathrm{mg} / \mathrm{mL}$ for endothelial cells and $2.5 \mathrm{mg} / \mathrm{mL}$ for other cells) for 30 min with $500 \mu \mathrm{M}$ hydrogen peroxide (aminotriazole inactivates catalase only in the presence of hydrogen peroxide). Glutathione levels and catalase activity were each significantly $(p<0.01)$ lower than levels in cells not exposed to BSO and aminotriazole (Table 1 ). The \% reduction compared with control cells is also provided.

$\mu \mathrm{Ci} / \mathrm{mL}(1.0 \mu \mathrm{Ci} /$ well $){ }^{51} \mathrm{Cr}$ (New England Nuclear, Boston, $\left.\mathrm{MA}\right)$ in media overnight as previously described $(10,24)$. Release of ${ }^{51} \mathrm{Cr}$ may be cell associated due to detachment of cells from the culture plate in response to oxidant stress or it may represent lytic injury with release of intracellular ${ }^{51} \mathrm{Cr}$ into the media (10, 26). To differentiate these two responses to oxidant injury, the media and wash portion of ${ }^{51} \mathrm{Cr}$-labeled cells were centrifuged for $3 \mathrm{~min}$, the supernatant was removed, and the supernatant and precipitate fractions were counted separately. The remaining intracellular label in cells that remained adherent to the culture plate was released with $2.0 \%$ Triton-X100; each fraction was counted in a Beckman gamma counter for $1 \mathrm{~min}$. Cell detachment, lytic injury, and total ${ }^{51} \mathrm{Cr}$ release were calculated as previously described (10); cell-associated ${ }^{51} \mathrm{Cr}$ release (representing detachment of cells from the culture plate) was calculated as $\mathrm{cpm}$ in the precipitate fraction/cpm in the precipitate fraction + $\mathrm{cpm}$ in the cell fraction that remained adherent to the culture plate, whereas release of ${ }^{51} \mathrm{Cr}$ representing lytic injury was calculated as cpm in the supernatant fraction/cpm in the supernatant fraction $+\mathrm{cpm}$ in the cell fraction that remained adherent to the culture plate. The sum of the release of the precipitate and supernatant fractions was the total ${ }^{51} \mathrm{Cr}$ release. Release of ${ }^{51} \mathrm{Cr}$ was determined $5 \mathrm{~h}$ after oxidant injury as previously described (10).

Statistical analysis. Data are presented as mean $\pm 1 \mathrm{SD}$. Analysis of variance with Student-Newman-Keuls multiple range test was used to detect differences in the response to oxidant stress in the presence and absence of BSO and aminotriazole, in detecting differences in the metabolism of hydrogen peroxide, and in detecting differences in glutathione levels, glutathione peroxidase, glutathione reductase, and catalase activity after log transformation to stabilize the variance.

\section{RESULTS}

Glutathione levels, glutathione peroxidase, glutathione reductase, and catalase activity. Glutathione levels, glutathione peroxidase, glutathione reductase, and catalase activity were measured in four to six different cohorts of endothelial and epithelial cells (Table 1). Among all cell lines, glutathione levels were not significantly different, ranging from $20.2 \pm 1.6 \mathrm{nmol} / \mathrm{mg}$ protein for NHK-C cells to $28.3 \pm 5.9 \mathrm{nmol} / \mathrm{mg}$ protein for OK cells. In contrast to minor differences in glutathione levels, the activity of catalase and glutathione reductase were each significantly $(p<$ 0.001 ) lower in endothelial cells compared with the four tubular epithelial cell lines. In addition, the activity of glutathione peroxidase was significantly $(p<0.05)$ lower in endothelial cells compared with all tubular epithelial cells except LLC-PK1 cells. Endothelial cell catalase activity was $3.5 \pm 1.0 \mathrm{U} / \mathrm{mg}$ protein compared with greater than $8.1 \pm 0.5 \mathrm{U} / \mathrm{mg}$ protein for each of the tubular epithelial cells, representing a more than 2-fold difference when compared with NHK-C cells and nearly a 9-fold difference when compared with LLC-PK1 and MDCK cells (Table 1). Among renal tubular epithelial cells, glutathione peroxidase activity was significantly $(p<0.05)$ higher in MDCK cells, whereas LLC-PK 1 cells had the lowest activity of glutathione peroxidase and the highest activity of glutathione reductase. Catalase activity was significantly $(p<0.05)$ higher in MDCK cells compared with all others except LLC-PK 1 cells.

Metabolism of exogenous hydrogen peroxide. To confirm the role of decreased antioxidant enzymes in the increased susceptibility of endothelial cells to oxidant stress, we determined the rate of metabolism of exogenous hydrogen peroxide in the five cell lines. The consumption of exogenous hydrogen peroxide was 

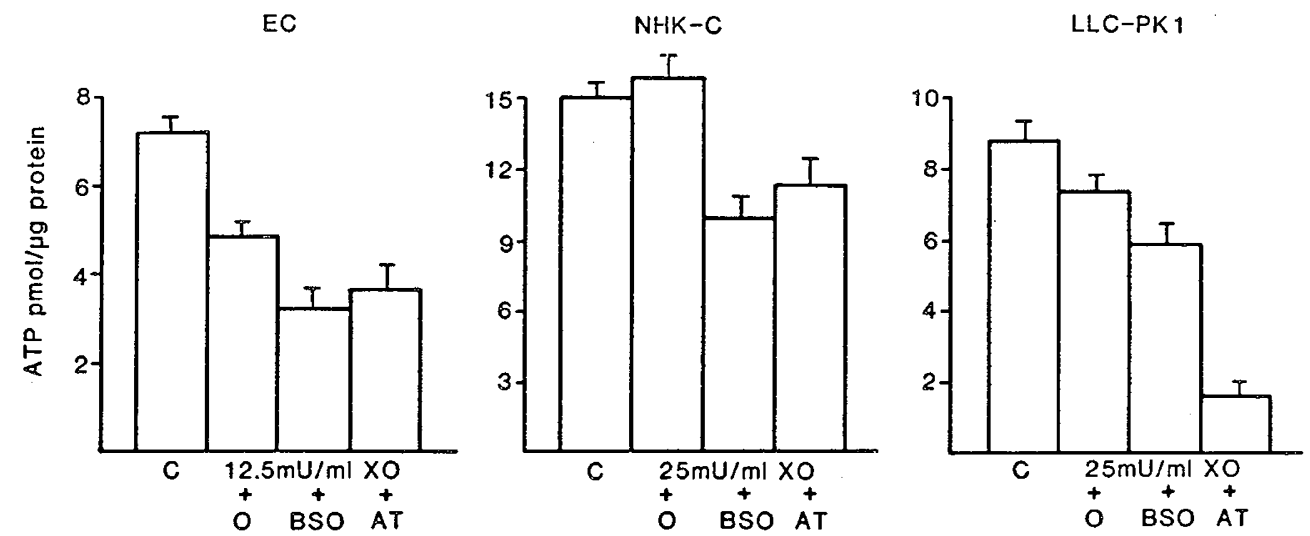

OK
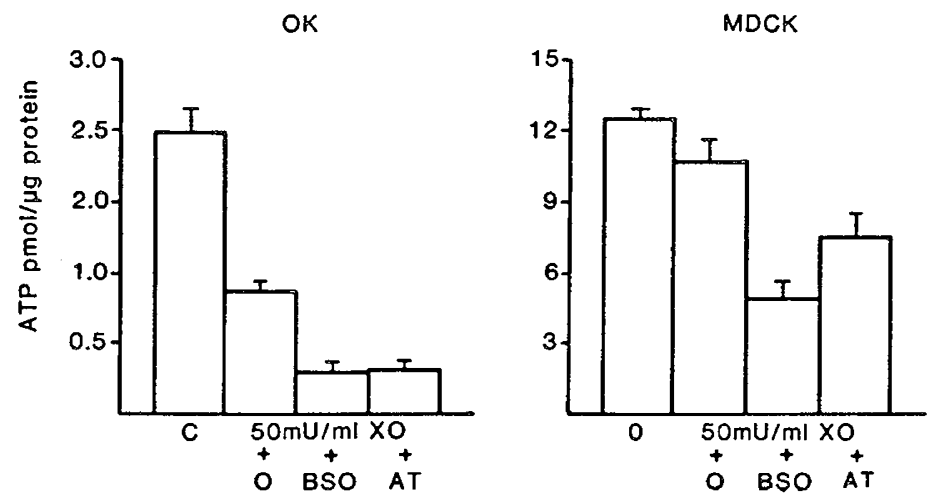

Fig. 2. ATP levels in human umbilical vein endothelial cells $(E C)$, LLC-PK1, NHK-C, OK, and MDCK cells in control cells $(C)$ and in cells exposed to xanthine oxidase with $5.0 \mathrm{mM}$ hypoxanthine and $1.0 \mathrm{mg} / \mathrm{mL}$ soybean trypsin inhibitor with no antioxidant inhibition $(O)$, with BSO, or with aminotriazole $(A T)$ for $1 \mathrm{~h}$. Cells were pretreated with BSO overnight or with aminotriazole for 30 min as described in Materials and Methods. When compared with ATP depletion without an antioxidant inhibitor $(O)$, ATP depletion was significantly $(p<0.01)$ accelerated when cells were exposed to hydrogen peroxide generated by xanthine oxidase and hypoxanthine when glutathione was depleted with BSO and when catalase was inhibited with aminotriazole in all cell types except endothelial cells. ATP values in control cells not exposed to oxidant stress are shown $(C)$. ATP values in cells exposed to BSO or aminotriazole in the absence of oxidant stress or to xanthine oxidase without hypoxanthine were greater than $90 \%$ of control values (data not shown). Values represent the mean \pm 1 SD of three to four replicates.

significantly slower $(p<0.001)$ in endothelial cells compared with all tubular cells (Fig. 1). The time to metabolize half the hydrogen peroxide was $33.5 \mathrm{~min}$ in endothelial cells, $13.7 \mathrm{~min}$ in LLC-PK1 cells, $13.5 \mathrm{~min}$ in OK cells, $14.5 \mathrm{~min}$ in MDCK cells, and $18.6 \mathrm{~min}$ in NHK-C cells. Among the tubular epithelial cells, NHK-C consumed hydrogen peroxide slightly but significantly $(p<0.01)$ slower than LLC-PK 1, OK, and MDCK cells. There was not a significant difference in the metabolism of exogenous hydrogen peroxide between LLC-PK1, OK, and MDCK cells.

Inhibition studies. When each cell line was incubated in 2.5 mM BSO overnight, glutathione levels were significantly $(p<$ 0.01 ) reduced (Table 2) to $10-26 \%$ of levels in cells not exposed to BSO (Table 1). This reduction is similar to levels previously observed to be associated with accentuated oxidant injury $(15$, $26,27)$. When endothelial cells and epithelial cells were exposed to aminotriazole in the presence of hydrogen peroxide, catalase activity was reduced to $10-20 \%$ of normal values (Table 2).

As a measure of an early response to oxidant stress, we determined ATP levels in each cell line with no antioxidant inhibitor, when glutathione was depleted with overnight incubation with $2.5 \mathrm{mM}$ BSO, and when catalase was inhibited with aminotriazole. As shown in Figure 2, glutathione depletion and catalase inhibition resulted in accelerated ATP depletion when cells were exposed to oxidant stress. In all cell lines except endothelial cells, oxidant-induced ATP depletion was significantly $(p<0.05)$ greater when cells were exposed to BSO and aminotriazole compared with cells exposed to oxidant stress without manipulation of antioxidant defenses. These studies demonstrate that both the glutathione redox cycle and catalase are important in protecting cells from oxidant-induced ATP depletion. ATP levels remained greater than $90 \%$ of control when the cells were exposed to BSO and aminotriazole in the absence of oxidant stress, whereas ATP levels were not significantly changed in cells exposed to xanthine oxidase in the absence of hypoxanthine (data not shown).

In contrast, lytic injury as determined with ${ }^{51} \mathrm{Cr}$ release was significantly $(p<0.05)$ greater in all cell lines except MDCK when glutathione was depleted with $\mathrm{BSO}$, whereas inhibition of catalase with aminotriazole resulted in accentuated lytic injury only in OK cells (Fig. 3). In endothelial cells, lytic injury was slightly greater in cells exposed to aminotriazole. In each cell line, the increase in ${ }^{51} \mathrm{Cr}$ release was found in the supernatant fraction, indicating that augmented injury was due to lytic injury rather than cell detachment. MDCK cells were resistant to detachment and lytic injury in spite of depressed endogenous antioxidant defenses. BSO and aminotriazole did not result in enhanced ${ }^{51} \mathrm{Cr}$ release in the absence of oxidant stress, and ${ }^{51} \mathrm{Cr}$ release in cells exposed to xanthine oxidase in the absence of hypoxanthine was less than $5 \%$ above control values (data not shown).

\section{DISCUSSION}

Enzymatic cellular defense mechanisms that protect organs and cells from injury mediated by reactive oxygen molecules include superoxide dismutase to dismute superoxide anion and the glutathione redox cycle and catalase to detoxify hydrogen 

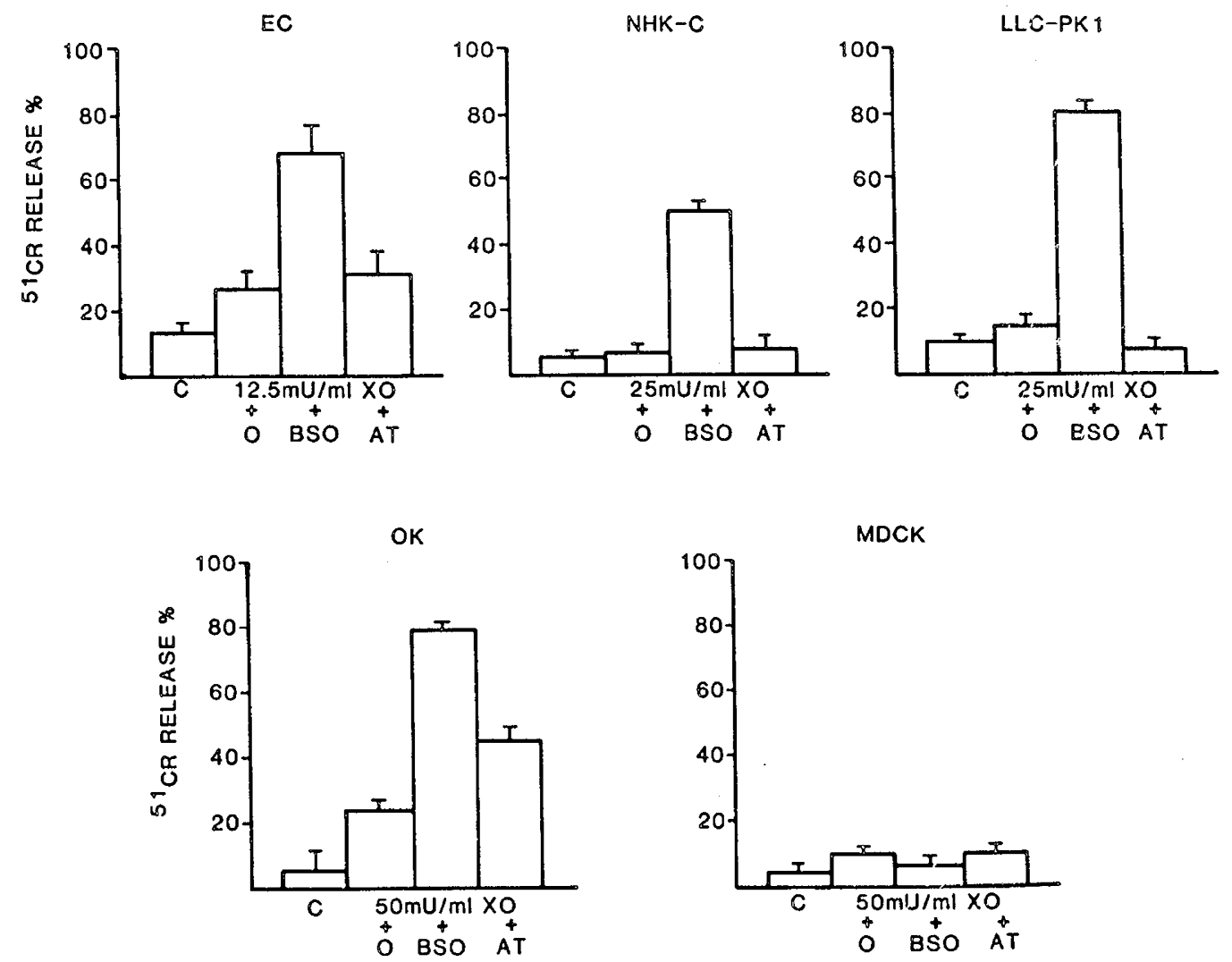

Fig. 3. Total ${ }^{51} \mathrm{Cr}$ release in human umbilical vein endothelial cells $(E C)$, LLC-PK1, NHK-C, OK, and MDCK cells in control cells $(C)$ and in cells exposed to xanthine oxidase with $5.0 \mathrm{mM}$ hypoxanthine and $1.0 \mathrm{mg} / \mathrm{mL}$ soybean trypsin inhibitor for $5 \mathrm{~h}$ with no antioxidant inhibitor $(O)$, with BSO, and with aminotriazole $(A T)$. Cells were pretreated with BSO overnight and with aminotriazole for 30 min as described in Materials and Methods. MDCK cells were very resistant to cell lysis and cell detachment in spite of glutathione depletion and catalase inhibition. In all other cell types, ${ }^{51} \mathrm{Cr}$ release was significantly $(p<0.01)$ enhanced when glutathione was depleted with BSO. In contrast, when catalase was inhibited with aminotriazole, ${ }^{51} \mathrm{Cr}$ release was significantly $(p<0.01)$ enhanced only in $\mathrm{OK}$ cells. Release of ${ }^{51} \mathrm{Cr}$ in control cells not exposed to oxidant stress is shown $(C)$. Values represent the mean $\pm 1 \mathrm{SD}$ of three to four replicates.

peroxide. Catalase metabolizes hydrogen peroxide, whereas the glutathione redox cycle maintains cellular thiols, detoxifies hydrogen peroxide and other hydroperoxides and lipid peroxides generated during oxidant stress $(9,21,27)$. In addition, other cellular characteristics are likely to play a role in the response of a cell to oxidant injury. In this study, we show that the enzymatic defense mechanisms important in detoxifying hydrogen peroxide are substantially lower in human endothelial cells than in the renal tubular epithelial cells. The activity of glutathione peroxidase, glutathione reductase, and particularly catalase was substantially lower in endothelial cells, suggesting a relationship between the lower antioxidant enzyme activity and their increased susceptibility to oxidant stress. Because human umbilical vein endothelial cells are derived from a relatively hypoxic environment, it is possible that the lower antioxidant enzyme activity of endothelial cells is related to a lack of oxidant stress in such an environment.

Among the renal tubular epithelial cells, differences in glutathione levels, glutathione reductase, and catalase activity did not fully explain the variable susceptibility of the renal tubular cells to oxidant stress. MDCK cells, the least susceptible of the tubular cells to oxidant stress, and LLC-PK1 cells, the most susceptible to oxidant injury, had similar levels of glutathione, catalase, and glutathione reductase activity. Because glutathione peroxidase catalyzes the regeneration of glutathione during oxidant injury, the higher activity in MDCK cells and lower activity in LLCPK1 cells suggest that such differences may play a role in their variable susceptibility to oxidant stress. However, the metabolism of exogenous hydrogen peroxide was very similar in each of the renal tubular epithelial cells lines, suggesting that additional factors other than the glutathione redox cycle and catalase activity are likely to play a role in the resistance of MDCK cells to oxidant injury. Such factors include the composition and susceptibility of cell membranes to lipid peroxidation, the content of nonenzymatic free radical scavengers such as vitamin $E$ and ascorbate, and the number and location of proteins that contain essential sulfhydryl groups for structural or enzymatic activity $(9,28,29)$.

Previous studies using release of ${ }^{51} \mathrm{Cr}$ or lactate dehydrogenase as an indicator of oxidant injury have demonstrated an important role for the glutathione redox cycle in maintaining endothelial cell integrity $(15,17,30)$. Other studies in renal tubular epithelial cells have also demonstrated an important role for the glutathione redox cycle in preventing oxidant injury $(31-35)$. Oxidant injury mediated by tert-butyl hydroperoxide is augmented by glutathione depletion and lessened when cellular levels of glutathione are increased (31-33). In vivo studies in rat kidneys suggest that antioxidant enzyme activity is an important determinant of oxidant-induced renal dysfunction (36). In this study, we confirm the role of the glutathione redox cycle in preventing lytic injury and we demonstrate a role for catalase as well as the glutathione redox cycle in protecting endothelial cells and epithelial cells from oxidant injury when a different indicator (ATP depletion) of oxidant injury is determined. The mechanism of this differential response is unknown but may be related to the role of the glutathione redox cycle in detoxifying lipid peroxides generated during the propagation of lipid peroxidation after oxidant stress, the role of the glutathione redox cycle in maintaining cellular thiols, or the compartmentalization of catalase and glutathione peroxidase within the cell $(8,27,35)$. 
After oxidant injury, several metabolic alterations occur, including activation of the glutathione redox cycle, elevation of intracellular calcium, DNA damage, and depletion of NAD and ATP stores $(24,25,37-39)$. Later changes include disruption of the cytoskeleton, resulting in blebbing, retraction, detachment, and ultimately cell lysis. Although multiple metabolic effects of oxidant injury have been elucidated, the events leading to irreversible injury and cell death are not well understood. DNA damage, NAD and ATP depletion, lipid peroxidation, elevation of intracellular calcium, and oxidation of protein thiols are each thought to be major mediators of oxidant injury by various investigators (37-42).

In this study, we found that accentuated oxidant-induced ATP depletion as a result of catalase inhibition did not result in accentuated lytic injury, suggesting that ATP depletion alone may not be a critical mediator of oxidant-induced cell death. We have previously demonstrated that oxidant-induced ATP depletion in endothelial and epithelial cells could be prevented with catalase but not with scavengers of hydroxyl radical (10). However, lytic injury was prevented with scavengers of hydroxyl radical and phenathroline, a membrane-permeable iron chelator to prevent the iron-catalyzed intracellular generation of hydroxyl radical from hydrogen peroxide (10). Similarly, a recent study in endothelial cells also demonstrated that oxidant-induced ATP depletion could not be prevented with the iron chelator deferoxamine, whereas ${ }^{51} \mathrm{Cr}$ release was prevented with deferoxamine (43). Taken together, these studies suggest that oxidant-induced ATP depletion alone does not lead to cell lysis and that other mechanisms of injury in addition to ATP depletion are likely to play a role in oxidant-induced cell death.

Acknowledgment. The authors thank Carl Langefeld for statistical analysis.

\section{REFERENCES}

1. Rehan A, Johnson KJ, Wiggins RC, Kunkel RG, Ward PA 1984 Evidence for the role of oxygen radicals in acute nephrotoxic nephritis. Lab Invest 51:396403

2. Shah SV 1989 Role of reactive oxygen metabolites in experimental glomerular disease. Kidney Int 35:1093-1106

3. Paller MS, Hoidal JR, Ferris TF 1984 Oxygen free radicals in ischemic acute renal failure in the rat. $J$ Clin Invest 74:1156-1164

4. Linas SL, Shanley PF, Whittenburg D, Berger E, Repine JE 1988 Neutrophils accentuate ischemia-reperfusion injury in isolated perfused rat kidneys. Am J Physiol 255:F728-F735

5. Andreoli SP 1991 Reactive oxygen molecules, oxidant injury, and renal disease. Pediatr Nephrol 5:733-742

6. Diamond JR, Bonventre JV, Karnovsky MJ 1986 A role for oxygen free radicals in aminonucleoside nephrosis. Kidney Int 29:478-483

7. Walker PD, Shah SV 1988 Evidence suggesting a role for hydroxyl radical in gentamicin-induced acute renal failure in rats. J Clin Invest 81:334-341

8. Topley N, Steadman R, Mackenzie R, Knowlden JM, Williams JD 1989 Type I fimbriate strains of Escherichia coli initiate renal parenchymal scarring. Kidney Int 36:609-616

9. Freeman BA, Crapo JD 1982 Free radicals and tissue injury. Lab Invest 47:412-426

10. Andreoli SP, McAteer JM 1990 Reactive oxygen molecule mediated injury in vitro: differential response by endothelial cells and renal tubular epithelial cells. Kidney Int 38:785-794

11. Hull EN, Cherry WR, Weaver GW 1976 The origin and characteristics of a pig kidney cell strain, LLC-PK1. In Vitro 12:670-677

12. Madin SH, Darby NB 1975 As catalogued in: American Type Culture Collection Catalogue of Strains, II. Rockville, MD, Am Type Culture Collection 2,47

13. Kempson SA, McAteer JA, Al-Mahrouq HA, Dousa TP, Dougherty GS, Evan AP 1989 Proximal tubule characteristics of cultured human renal cortex epithelium. J Lab Clin Med 113:285-296
14. Jaffe EA, Hoger LW, Nachman RL 1973 Synthesis of anti-hemophylic factor antigen by cultured human endothelial cells. J Clin Invest 52:2757-2764

15. Andreoli SP, Mallett CH, Bergstein JM 1986 Role of glutathione in protecting endothelial cells against hydrogen peroxide oxidant injury. J Lab Clin Med 108:190-198

16. Tietze F 1969 Enzymatic method for quantitative determination of nanogram amounts of total and oxidized glutathione. Anal Biochem 27:502-522

17. Suttorp N, Toepfer W, Roka L 1986 Antioxidant defense mechanisms of endothelial cells: glutathione redox cycle versus catalase. Am J Physiol 251:C671-C680

18. Baughman RP, Corser BC, Strohofer S, Hendricks D 1986 Spontaneous hydrogen peroxide release of alveolar macrophages of some cigarette smokers. J Lab Clin Med 107:233-237

19. Lowry OH, Rosebrough NHJ, Farr AL, Randall RJ 1951 Protein measurement with the Folin phenol reagent. J Biol Chem 193:265-275

20. Margoliash EA, Novogrodsky A, Schejter A 1960 Irreversible reaction of 3amino-1:2:4-triazole and related inhibitors with the protein of catalase. $\mathrm{J}$ Pharmacol Exp Med 74:339-348

21. Meister A 1983 Selective modification of glutathione metabolism. Science 220:472-477

22. Ager A, Wenham DJ, Gordon L 1984 Stimulation of endothelial cells by protease activity in commercial preparations of xanthine oxidase. Thrombosis Res 35:43-52

23. Stanley PE, William SG 1969 Use of the liquid scintillation spectrometer for determining adenosine triphosphate by the luciferase enzyme. Anal Biochem 29:381-392

24. Spragg RG, Hinshaw DB, Hyslop PA, Schraufstatter IU, Cochrane CG 1985 Alteration in adenosine triphosphate and energy charge in cultured endothelial and P388D1 cells after oxidant injury. J Clin Invest 76:1471-1476

25. Andreoli SP 1989 Mechanisms of endothelial cell ATP depletion after oxidant injury. Pediatr Res 25:97-101

26. Harlan JM, Killen PD, Harker LA, Striker GE 1981 Neutrophil-mediated endothelial injury in vitro: mechanisms of cell detachment. J Clin Invest 68:1394-1403

27. Reed DL 1990 Glutathione: toxicologic implications. Ann Rev Pharmacol Toxicol 30:603-631

28. Machlin LJ, Bendich A 1987 Free radical tissue damage: protective role of antioxidant nutrients. FASEB J 1:441-445

29. Wispe JR, Knight M, Roberts RJ 1986 Lipid peroxidation in newborn rabbits: effects of oxygen, lipid emulsion, and vitamin E. Pediatr Res 20:505-510

30. Harlan JM, Levine JD, Callahan KS, Schwartz BR 1984 Glutathione redox cycle protects cultured endothelial cells against lysis by extracellularly generated hydrogen peroxide. J Clin Invest 73:706-713

31. Hagen TM, Aw TY, Jones DP 1988 Glutathione uptake and protection against oxidative injury in isolated kidney cells. Kidney Int 34:74-81

32. Messana JM, Cieslinski DA, O'Connor RP, Humes HD 1988 Glutathione protects against exogenous oxidant injury to rabbit renal proximal tubules. Am J Physiol 255:F874-F884

33. Schnellmann RG 1988 Mechanisms of t-butyl hydroperoxide-induced toxicity to rabbit renal proximal tubules. Am J Physiol 255:C28-C33

34. Linas SL, Shanley PF, White CW, Parker NP, Repine JE 1987 O, metabolitemediated injury in perfused kidneys is reflected by consumption of DMTU and glutathione. Am J Physiol 253:F692-F701

35. McCoy EN, Hill KE, Ayon MA, Stein JH, Burk RF 1988 Oxidant stress following renal ischemia: changes in the glutathione redox ratio. Kidney Int 33:812-817

36. Yoshioka T, Bills T, Moore-Jarrett T, Greene HL, Burr IM, Ichikawa I 1990 Role of intrinsic antioxidant enzymes in renal oxidant injury. Kidney Int 38:282-288

37. Schraufstatter IU, Hyslop PA, Jackson JH, Cochrane CG 1988 Oxidantinduced DNA damage of target cells. J Clin Invest 82:1040-1050

38. Hyslop PA, Hinshaw DB, Schraufstatter IU, Sklar LA, Spragg RG, Cochrane CG 1986 Intracellular calcium homeostasis during hydrogen peroxide injury to cultured P388D 1 cells. J Cell Physiol 129:356-366

39. Hyslop PA, Hinshaw DB, Halsey Jr WA, Schraufstatter IU, Sauerheber RD, Spragg RG, Jackson JH, Cochrane CG 1985 Mechanisms of oxidant mediated cell injury. J Biol Chem 263:1665-1675

40. Farber JL, Kyle ME, Coleman JB 1990 Mechanisms of cell injury by activated oxygen species. Lab Invest 62:670-679

41. Orrenius S, McConkey DJ, Nicotera P 1988 Mechanisms of oxidant-induced cell damage. In: Oxy-Radicals in Molecular Biology and Pathology. Alan R Liss, New York, pp 327-339

42. Kirkland JB 1991 Lipid peroxidation, protein thiol oxidation and DNA damage in hydrogen peroxide-induced injury to endothelial cells: role of activation of poly (ADP-ribose) polymerase. Biochim Biophys Acta 1092:319-325

43. Varani J, Phan SH, Gibbs DF, Ryan US, Ward PA $1991 \mathrm{H}_{2} \mathrm{O}_{2}$ mediated cytotoxicity of rat pulmonary endothelial cells. Lab Invest 63:683-689 